\section{The research, development, and innovation trajectory of the IAC Common Bean Breeding Program}

\section{Luiza Maria Capanema Bezerra ${ }^{1 *}$, Carlos Eduardo Fredo ${ }^{2}$, Alisson Fernando Chiorato $^{1}$ and Sérgio Augusto Morais Carbonell ${ }^{1}$}

\begin{abstract}
Since 1932, the Common Bean Breeding Program of the Instituto Agronômico (PMGF-IAC) has provided bean cultivars with high yield potential and stability, grain of high technological quality and nutritional value, resistance and tolerance to the main common bean diseases, and commercial acceptance. This article presents the main results of the PMGF-IAC from a study of its research, development, and innovation (RD\&I) trajectory and from information regarding adoption of cultivars (from 1932 to 2019). The main contributions of this study are (i) to display the trajectory of RD\&I in common bean breeding in IAC, (ii) to present a description of common bean cultivars of different commercial types recommended over the period analyzed, and (iii) to provide an analysis of adoption of the new cultivars. This study is directed to researchers that develop common bean cultivars or that act in the sphere of science, technology, and innovation.
\end{abstract}

Keywords: Phaseolus vulgaris L., common bean, dry bean, cultivar, plant breeding program.

\section{INTRODUCTION}

The common bean grain consumed in Brazil is a seed of a leguminous plant of the Phaseolus genus. The main Phaseolus species grown throughout the world are Phaseolus vulgaris L., P. lunatus L., P. coccineus L., P. acutifolius A. Gray var. latifolius Freeman, and P. polyanthus Greenman (Debouck et al. 1991). The species most highly represented in growing and consumption is Phaseolus vulgaris L., commonly known in Brazil as feijoeiro (including dry edible bean and snap/green bean), hereinafter "bean".

Bean is an important food and contributes to food security for diverse populations worldwide, due to its low cost of production, low price, and high nutritional quality ${ }^{1}$. A considerable part of worldwide bean production supplies families of lower purchasing power, given its accessible price compared to sources of animal protein (Hartmann and Siegrist 2017, Asare-Marfo et al. 2019). Studies have revealed the behavioral patterns of bean consumers, who seek nutritional quality, control of chronic diseases (diabetes, obesity, heart problems, and cancer), environmental sustainability, and low impact on the household budget (Curran 2012, Hayat et al. 2014, Darmon and Drewnowski 2015, Allès et al. 2017).

${ }^{1}$ Beans are an important source of protein. For a 2,000-calorie daily diet, consumption of $100 \mathrm{~g}$ of cooked beans represents $8 \%$ of the daily protein intake. It is also rich in fiber, calcium, iron, and B vitamins (Câmara et al. 2013, Messina 2014).
Crop Breeding and Applied Biotechnology 21(2): e36872124, 2021 Brazilian Society of Plant Breeding. Printed in Brazil http://dx.doi.org/10.1590/198470332021v21n2a33
*Corresponding author:
E-mail: luiza.bezerra@sp.gov.br
(i) ORCID: 0000-0002-5906-4645

Received: 12 January 2021 Accepted: 22 June 2021 Published: 20 July 2021

\footnotetext{
${ }^{1}$ Instituto Agronômico (IAC), Centro de Análises e Pesquisa Tecnológica do Agronegócio dos Grãos e Fibras, Av. Barão de Itapura, 1.481, 13.020-902, Campinas, SP, Brazil

${ }^{2}$ Instituto de Economia Agrícola (IEA), Centro de Pesquisa de Informações Estatísticas dos Agronegócios. Praça Ramos de Azevedo, 254, 01.037-912, São Paulo, SP, Brazil
} 
The search for crop improvements in aspects such as nutritional quality, environmental sustainability, yield, and multiple disease resistance motivates researchers to develop research, development, and innovation (RD\&I) activities in various areas of knowledge (e.g., nutrition, genetics), and, in this case, in research dedicated to the breeding of common bean. An analysis of the Common Bean Breeding Program of the Instituto Agronômico (Programa de Melhoramento Genético de Feijoeiro do Instituto Agronômico - PMGF-IAC) presented in this article highlights these aspects. In this paper, we refer to the research program by using its acronym in Portuguese (PMGF-IAC).

The aim of this article is to present the trajectory of RD\&I of the PMGF-IAC, highlighting its main results from 1932 to 2019. The results of this study can contribute to discussion of the research trajectory of common bean in Brazil. This study provides information relevant to the management of other research programs oriented toward results to meet the demands of the production sector, such as the release of cultivars with adaptability to different growing environments and with yield stability.

\section{MATERIAL AND METHODS}

The study of the trajectory of RD\&I and the results of the PMGF-IAC comprise information from 1932 to 2019 and are based on a bibliographical and documental review. The study also analyzed the transfer and adoption of technology and interviewed breeders from the program in May 2020. The aim of the interviews was to validate the information on the three periods proposed for studying the trajectory of RD\&l, on the fields of research, and on their results. This information is presented in Figures 1 to 3 and Tables 1 to 3.

The information analyzed regarding the transfer and adoption of cultivars on the part of the PMGF-IAC resulted in a quantitative-descriptive study of the following variables: bean commercial types (carioca, black, and rajado), IAC bean cultivars, quantity of seed authorized for sowing, planted area, and number of licensing contracts for seed production from 2010 to 2019. This period was selected due to the availability of information in the database of the PMGF-IAC technology transfer system regarding partnerships and contracts for the use of IAC bean cultivars. The results were organized on MS OFFICE Excel software. These data also served as a basis for creating a map using ArcGis software, which allowed spatialization of the quantity of seed authorized for multiplication per cultivar.

A total of 675 seed production licensing contracts (authorizations of seed multiplication fields) were analyzed for 12 IAC bean cultivars (IAC 1849 Polaco, IAC 1850, IAC Alvorada, IAC Boreal, IAC Formoso, IAC Harmonia, IAC Imperador, IAC Milênio, IAC Netuno, IAC Nuance, IAC Sintonia, and IAC Veloz). For this study, the seed producers are considered partners of the PMGF-IAC, and they currently represent the main commercial agents in the bean seed market in Brazil. The document "authorization of seed multiplication fields" issued by the program is an authorization from the holder of the intellectual property rights of the cultivar, and is a requirement foreseen within the scope of the legal framework that regulates seed production in Brazil.

\section{RESULTS AND DISCUSSION}

A key event in the institutionalization of plant breeding activities in Brazil was the founding of the Estação Agronômica de Campinas (Campinas Agronomic Station) in 1887, currently denominated the Instituto Agronômico (IAC) (Ramalho et al. 2012). In 1927, the IAC Genetics Sector was created, which established the basis for the rise of plant breeding programs of importance for development of Brazilian agriculture, involving cotton, coffee, bean, sugarcane, wheat, grape, and other crops (Furlani and Viégas 1993). Research activities in bean breeding began in 1932, which distinguishes the program as the oldest common bean breeding program in Brazil (Pompeu 1993). From 1932 to 2019, the results of the program were based on the interaction among RD\&l, the demands of the production chain (agricultural production, packaging industry, and consumption), and the evolution of the legal and regulatory framework. The legal and regulatory framework deals with rights to legal protection of cultivars and the proposal of establishment of the National System of Seeds and Seedlings (Sistema Nacional de Sementes e Mudas) (BRASIL 1997, 2003). The trajectory of RD\&I of the PMGF-IAC was divided into three periods (1932-1972, 1973-1998, 1999-2019), highlighting the main fields of research, their results, and the key elements of alignment among the programs, production sector, and legal and regulatory framework (Figure 1).

The interval of 1932-1972 corresponds to building the foundation for research on bean at IAC. In that period, the breeding method used was mass selection of local varieties. The breeding objectives were resistance to the main bean 


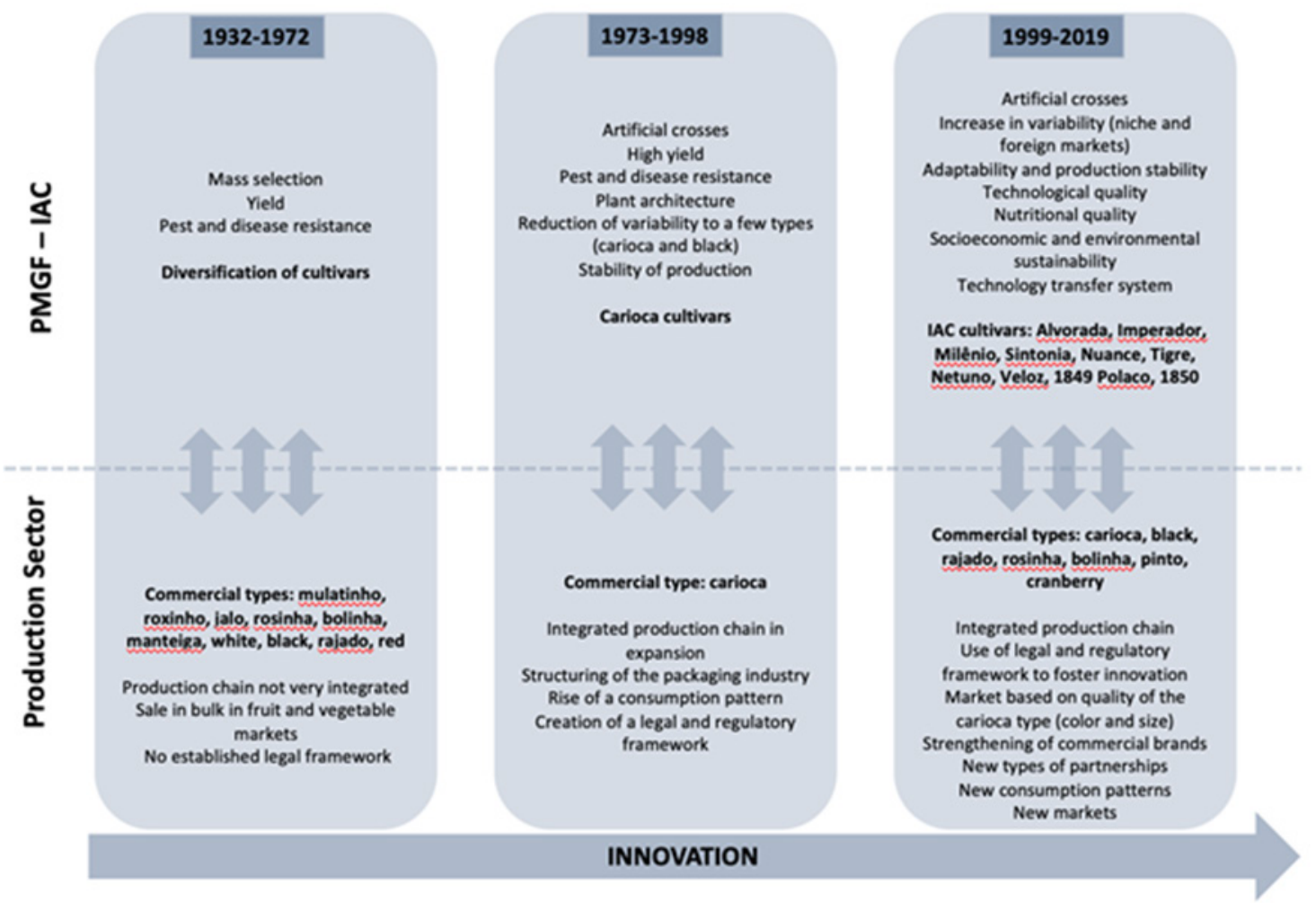

Figure 1. Trajectory of research, development, and innovation (RD\&I) of the Bean Breeding Program of the Instituto Agronômico (PMGF-IAC,1932-2019).

pathogens, yield, and product quality. The cultivars resulting from that effort were multiplied and distributed to local farmers. There was a wide variety of bean types at that time, both in the crop systems and in the consumer market. At the end of the 1960s, the carioca (cream-colored seed coat with brown streaks) variety began to be introduced in the IAC plant collection (Pompeu 1993, Chiorato et al. 2018b). Experimentation and tests of the carioca variety led to commercial release of the $\mathrm{cv}$. Carioca in the following period.

In the 1973-1998 period, RD\&I was based on genealogical and backcrossing selection methods. That period was marked by the adoption and spread of the carioca bean type. The adoption of carioca allowed the stabilization of bean production throughout Brazil, contributing to the uniformity and improvement in the quality of beans consumed by Brazilians (Chiorato et al. 2018b). Thus, the increase in the supply of superior quality beans was fundamental for structuring the packaging industry and for consolidation of a Brazilian consumption pattern based on the carioca commercial type (Chiorato et al. 2018b). Furthermore, a noteworthy aspect of that period is consolidation of the legal and regulatory framework for protection rights and commercial registration of cultivars (Carbonell et al. 2012, Santos et al. 2012, Chiorato et al. 2018b). This legal and regulatory framework was the basis for constitution of the Technology Transfer System of the PMGF-IAC that arose in the following period.

The period from 1999 on was also based on genealogical and backcrossing methods, and important elements that evolved were identified in the trajectory of RD\&I of the PMGF-IAC: a greater diversity of research areas, results with higher adherence to the demands of the production sector, and a proposal for a technology transfer system. The technology transfer system was established for formalization of contracts with partners for use of IAC bean cultivars, which was induced by the law for cultivar protection (BRASIL 1997). This system was considered an innovative model in IAC, created with the aim of expanding adoption of cultivars and dedication of resources for funding RD\&I.

Throughout the trajectory of RD\&I of the PMGF-IAC, there have been 50 generations of commercially recommended bean cultivars. IAC common bean cultivars released, and registered followed regulations foreseen in ministerial order 
no. 527 of 31 December 1997 that instituted the Brazilian National Cultivar Registry (BRASIL 1998). More details on the cultivars and on the evolution of the main breeding traits from the genetic base of the PMGF-IAC can be found in Tables 1 to 3.

The study of the trajectory of RD\&I of the PMGF-IAC allowed identification of the following results:

- Development of strategies of plant breeding and technology transfer, directing efforts and resources to the pursuit of genetic progress for yield, resistance and tolerance to abiotic and biotic factors, technological quality ${ }^{2}$ and nutritional quality, early maturity, and biofortification (Carbonell et al. 2010, Carbonell et al. 2014, Carbonell et al. 2019, Chiorato et al. 2010, Chiorato et al. 2012, Maringoni et al. 2015, Ribeiro et al. 2017, Chiorato et al. 2018b, Gonçalves et al. 2019, Spitti et al. 2019)

- Establishment of bean as a viable agribusiness option in Brazil through provision of the IAC Carioca cultivar, which allowed stability of production, structuring of the bean packaging industry, and a market standard to meet the growing demand for beans with that type of seed coat (Carbonell et al. 2012, Chiorato et al. 2018b)

- Recommendation of 50 cultivars of bean of different commercial types (Tables 1, 2, and 3).

The contextualization of the trajectory of the PMGF-IAC is supplemented by analysis of information on the transfer and adoption of IAC bean cultivars from 2010 to 2019. This information constitutes the most recent and representative results of a learning process that began in the period 1973-1998, guided by implementation of the legal framework that deals with protection rights and commercial registration of cultivars. Thus, between the years 2010 and 2019, 12 IAC bean cultivars were adopted, 675 licensing contracts were established with 76 partners, and 1,670.8 tons of seed were authorized for planting (different categories) on 25,503.4 ha of seed multiplication fields.

Table 1. Generations of IAC common bean cultivars (1963-1993)

\begin{tabular}{|c|c|c|c|}
\hline Cultivar & Year & Type & Improved traits \\
\hline Rosinha G2 & 1963 & Rosinha & Yield and cooking quality \\
\hline Preto G1 & 1963 & Black & Yield and rust resistance \\
\hline Pintado & 1965 & Pintado & Yield and cooking quality \\
\hline Goiano Precoce & 1966 & Jalo & Early maturity \\
\hline luba 1 & 1968 & Mulatinho & Early maturity \\
\hline luba 2 & 1968 & Mulatinho & Early maturity \\
\hline Aeté 2 & 1968 & Mulatinho & Resistance to common mosaic virus and rust \\
\hline Carioca/Carioquinha & 1970 & Carioca & Yield and stability \\
\hline Piratã 1 & 1971 & Black & Resistance to common mosaic virus and rust \\
\hline Aroana & 1978 & Mulatinho & Yield and multiple disease resistance \\
\hline Moruna & 1978 & Black & Yield and multiple disease resistance \\
\hline Carioca 80 & 1980 & Carioca & Resistance to race 65 of anthracnose \\
\hline Catú & 1980 & Black & Resistance to common mosaic virus and rust \\
\hline Moruna 80 & 1980 & Black & Resistance to anthracnose, common mosaic virus, and rust \\
\hline Carioca $80 \mathrm{SH}$ & 1988 & Carioca & Removal of orange halo on the seed \\
\hline IAC Una & 1993 & Black & Early maturity, resistance to anthracnose, and broth quality \\
\hline IAC Maravilha & 1993 & Black & Resistance to anthracnose and broth quality \\
\hline
\end{tabular}

Source: Elaborated by the authors, IAC Common Bean Breeding Program

${ }^{2}$ The technological quality of the bean grain refers to its response to the cooking process, which depends on the water absorption capacity of the grain, the seed coat characteristics, the quality of the grain at harvest (genetic characteristics), the storage conditions, and the processing techniques adopted (Carbonell et al. 2003). 
The quantity of bean seed authorized for sowing from the breeding program was calculated considering the total area of bean sown (from the CONAB dataset) for the crop years from 2009/10 to 2018/19. A total of 1,670.8 tons of IAC bean seeds (commercial types: carioca, rajado, and black) was considered in this calculation. We considered that $60 \mathrm{~kg}$ of seed are used per hectare, and an average yield of $1,800 \mathrm{~kg} \mathrm{ha}^{-1}$ is obtained. The calculation also considered that three multiplication operations (sowing) were performed for the following categories: genetic, basic, and C1. The share of IAC bean cultivars in the seed market was $6.9 \%(2,234,690 \mathrm{ha})$, considering the total planted area of bean of Brazil $(32,437,640$ ha).

The IAC cultivar Imperador (released in 2012) and Milênio (released in 2013) are of the carioca commercial type (Table 3). These two cultivars accounted for $64.5 \%$ of the total seed authorized for sowing. Seed production of the IAC Imperador cultivar increased from $930 \mathrm{~kg}$ (2012) to approximately 171 tons (2016) (Figure 2), and simultaneously, there was considerable increase in planted area (from 14.7 ha to 2.6 thousand ha). Authorization and licensing contracts for seed production of the IAC Milênio cultivar increased from 3 to 65 . The prominence of these cultivars was due to their agronomic traits, such as early cycle and resistance to anthracnose and fusarium wilt, among others (Chiorato et al. 2012, Carbonell et al. 2014).

Table 2. Generations of IAC common bean cultivars (1994-2007)

\begin{tabular}{|c|c|c|c|}
\hline Cultivar & Year & Type & Improved traits \\
\hline IAC Carioca Pyatã & 1994 & Carioca & Plant architecture and resistance to anthracnose and bacterial wilt \\
\hline IAC Bico-de-Ouro & 1994 & Bico-de-ouro & Yield, plant architecture, and multiple disease resistance \\
\hline IAC Carioca Aruã & 1996 & Carioca & Resistance to bacterial wilt and light-colored grain \\
\hline IAC Carioca Akytã & 1996 & Carioca & Yield and resistance to angular leaf spot and bacterial wilt \\
\hline IAC Carioca Eté & 1999 & Carioca & Resistance to golden mosaic virus and to bacterial wilt \\
\hline IAC Carioca Tybatã & 2001 & Carioca & Plant architecture and resistance to anthracnose and bacterial wilt \\
\hline IAC Ybaté & 2005 & Carioca & Yield and plant architecture \\
\hline IAC Tunã & 2006 & Black & Plant architecture and broth quality \\
\hline IAC Alvorada & 2007 & Carioca & Resistance to fusarium wilt, grain quality, and tolerance to high temperature \\
\hline IAC Harmonia & 2007 & Rajado & Resistance to anthracnose and angular leaf spot \\
\hline IAC Boreal & 2007 & Rajado & Yield and multiple disease resistance \\
\hline
\end{tabular}

Source: Elaborated by the authors, IAC Common Bean Breeding Program.

Table 3. Generations of IAC common bean cultivars (2008-2018)

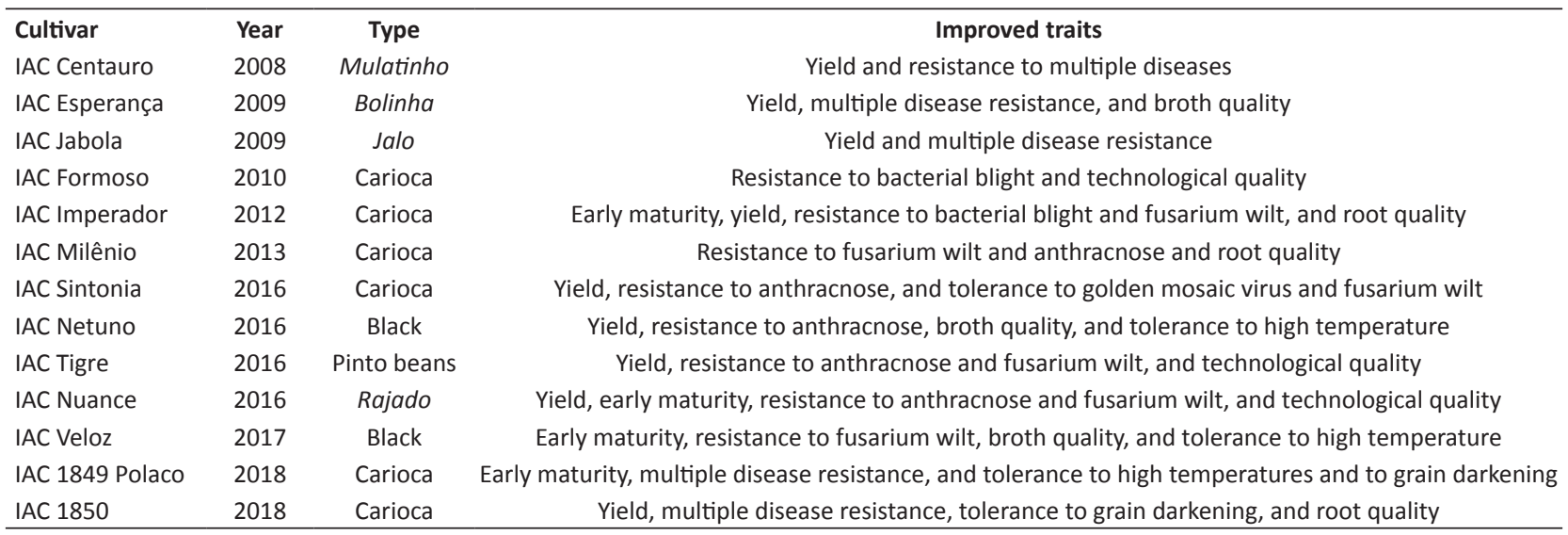

Source: Elaborated by the authors, IAC Common Bean Breeding Program. 


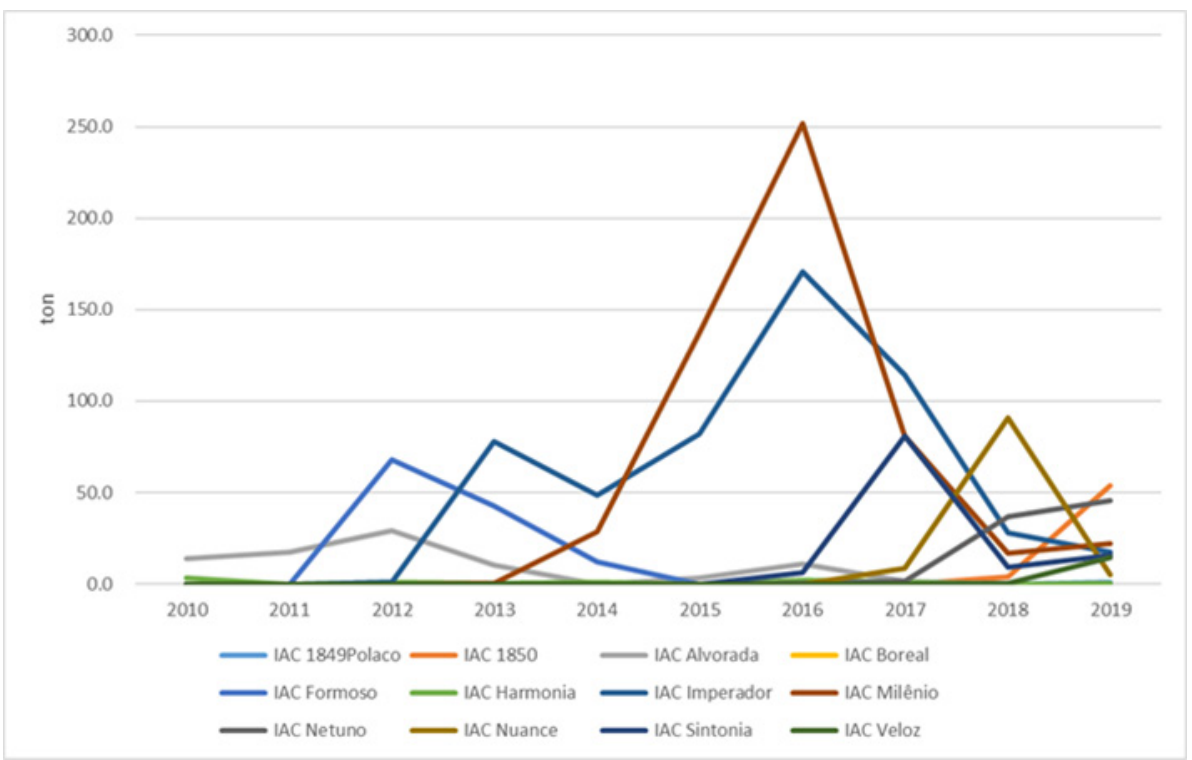

Figure 2. Quantity of seed (tons) licensed for bean multiplication per cultivar, IAC, 2010 to 2019.

* Data comprise the following seed categories: genetic, basic, C1, C2, S1, and S2.

IAC Sintonia (a carioca type), released in 2016 (Table 3), represented 6.7\% of the total amount of seed authorized for sowing. This cultivar had its highest volume in 2017, with 80.7 tons of seed authorized for multiplication, decreasing its representativeness in the following year and reaching 15.4 tons in 2019 (Figure 2). This cultivar may have low resistance to darkening when stored, which is an undesirable characteristic for the Brazilian consumer (Chiorato et al. 2018a). Initially there was greater concentration of areas authorized for multiplication of seed in the state of Goiás, a production region in which the bean grain is stored before the stage of distribution to packaging companies. However, due to the darkening of the stored grain, use of the cultivar declined in Goiás. In contrast, use of this cultivar increased in the states of Paraná and Santa Catarina (Figure 3) because beans are not often stored there after harvest, which allows sale of IAC Sintonia before darkening of the seed coat.

The cultivars IAC 1849 Polaco and IAC 1850, carioca types, show good resistance to seed coat darkening; they were released in 2018 (Table 3) (Carbonell et al. 2019). Initially, these cultivars exhibited quantities of seed authorized for sowing higher than those identified for IAC Imperador and IAC Milênio, due to the credibility earned by the IAC bean cultivars in previous years. As shown in Figure 2, IAC 1849 Polaco and IAC 1850 represented $3.5 \%$ of the total quantity of seed authorized for sowing. Authorization for sowing of IAC 1850 began in 2018 with 4.1 tons of seed and, in the following year, it achieved an expressive 53.9 tons of seed for sowing. In 2019, the authorized area was 805 ha and 30 contracts. Data for the IAC 1849 Polaco cultivar were only for 2019: 1.3 tons, 18 ha, and 2 contracts.

The carioca-type bean was the commercial type most licensed to seed producers from 2010 to 2019. Considering all carioca-type beans, 1,459.2 tons of seed were authorized for sowing among the different cultivars and categories for seed multiplication, which corresponded to $87.3 \%$ of the total seeds transferred to those who requested them in the period. These results are aligned with the RD\&I strategies of the PMGF-IAC, considering the prioritization of processes of selection of carioca bean cultivars for identification of superior genotypes and considering the consumption pattern of the Brazilian population. The production sector has sought to establish multiplication contracts for the carioca commercial type more than any other type.

The desirable characteristics of the black bean cultivars IAC Netuno (released in 2016) and IAC Veloz (released in 2018) were high yield, tolerance to high temperature, and the quality of their bean broth. Together, these two cultivars had a $5.9 \%$ share of the total quantity of seed authorized for sowing. The quantity of authorized seeds of IAC Netuno increased from $200 \mathrm{~kg}$ in 2016 (release) to 45.6 tons in 2019 (Figure 2). In that period, the area sown with the IAC Netuno 
cultivar increased from 4 ha to 741 ha, and the number of authorization and licensing contracts increased from 1 to 25 . The number of licensing contracts and the area of seed multiplication for the IAC Netuno cultivar is notable. It is first registered in licensing contracts beginning in 2016 and represented 5.9\% of the seeds authorized by the PMGF-IAC. At the beginning of the period of analysis, only $200 \mathrm{~kg}$ of seed was transferred for multiplication in the production sector. In 2016, this quantity was less than 1 ton, but in 2019 the quantity of seed transferred was 60 tons.

IAC Nuance, rajado bean type, is directed toward export and represented $6.2 \%$ of the total seed authorized for sowing, adding up to 104.2 tons of seed transferred (Figure 2), 972.9 ha planted area, and 27 licensing contracts.

The quantity of IAC bean cultivar seed authorized for sowing in Brazil is presented in Figure 3. In the period evaluated, ten Brazilian states/district requested authorization for multiplication of IAC bean seeds, and the states of Goiás, Minas Gerais, and Paraná stand out for the quantity of IAC bean cultivar seed produced. The IAC Imperador cultivar (carioca commercial type) was the cultivar most adopted in these three states. The IAC Netuno cultivar was the black seed coat cultivar most adopted in the states of Minas Gerais and Paraná, whereas IAC Formoso stood out in Goiás. Approximately $50 \%$ of the seed authorized for the IAC Nuance cultivar was sown in Goiás. Although Rio Grande do Norte is not among

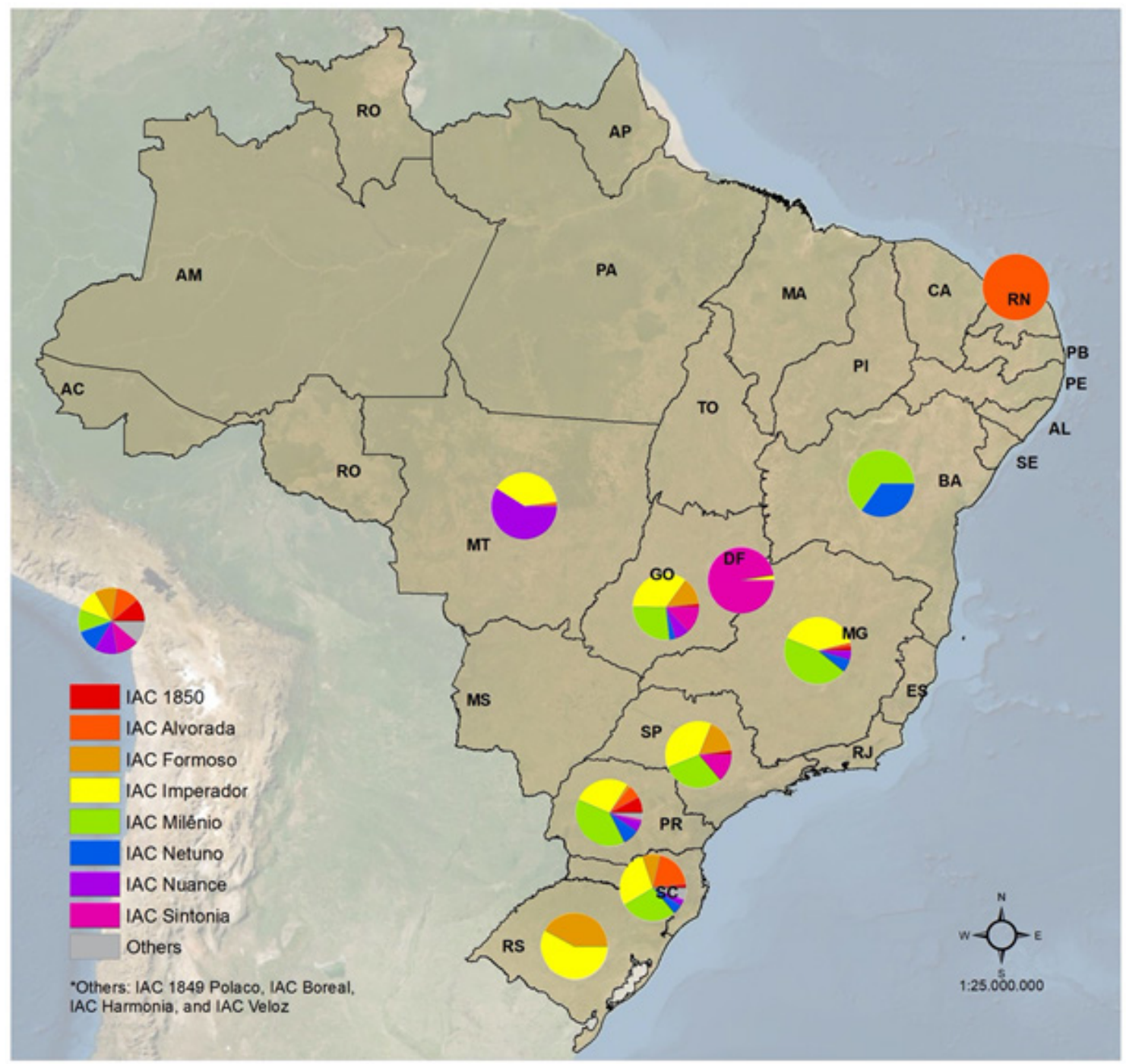

Figure 3. Spatialization of the total seed authorized for sowing by IAC with IAC bean cultivars, Brazil, 2010-2019. * Data comprise the following seed categories: genetic, basic, C1, C2, S1, and S2. 
the main bean producers in Brazil, seeds were requested from the PMGF-IAC by that state for the implementation of public policies aimed at the development of family farming. In that state, there was demand for the IAC Alvorada cultivar, which adapted to the growing conditions of the region, exhibiting agronomic attributes such as light-colored bean grain and tolerance to high temperature (Table 2) (Carbonell et al. 2008).

\section{CONCLUSIONS}

Our case study on the PMGF-IAC has provided original results that allow identification of key elements that constitute the foundations of the program. The following elements should be taken into account in analysis of the results: i) the trajectory of RD\&I in bean breeding; ii) the strengthening of strategies in recent years, such as the identification of superior genotypes related to grain quality, resistance to fusarium wilt, anthracnose, and grain darkening, as well as the diversification of the portfolio of cultivars, which has allowed higher alignment of results with the demands of the production chain; iii) the establishment of a technology transfer system, which has increased the actions of technological dissemination and the diversification of financial resources to be spent on RD\&l; and iv) the capability of adapting to market trends, such as new types of grains for domestic and foreign markets.

\section{ACKNOWLEDGMENTS}

The research project "Evaluation of the Results and Impacts of the Bean Breeding Program of the Agronomic Institute" was funded by the São Paulo Research Foundation (FAPESP), Government of the State of São Paulo, Brazil - Grant 2020/01721- 7, and the National Council for Scientific and Technological Development (CNPq), Brazil - Grant 422680/2018-4.

\section{REFERENCES}

Allès B, Baudry J, Méjean C, Touvier M, Péneau S, Hercberg S and KesseGuyot E (2017) Comparison of sociodemographic and nutritional characteristics between self-reported vegetarians, vegans, and meateaters from the nutrinet-santé study. Nutrients 9: 1023.

Asare-Marfo D, Herrington C, Alwang J, Birachi E, Birol E, Diressie MT, Dusenge L, Funes J, Katungi E, Labarta R, LaRochelle C, Katsvairo L, Lividini K, Lubowa A, Moursi M, Mulambu J, Murekezi B, Musoni A, Nkundimana J d'Amour, Oparinde A, Vaiknoras $K$ and Zeller $M$ (2019) Assessing the adoption of high iron bean varieties and their impact on iron intakes and other livelihood outcomes in Rwanda. HarvestPlus, CIAT and IFPRI, Washington, DC, 43p.

BRASIL (1997) Lei no 9.456, de 25 de abril de 1997. Institui a Lei de Proteção de Cultivares e dá outras providências. Available at < http://www.planalto.gov.br/ccivil_03/leis/19456.htm>. Accessed on November 16, 2020.

BRASIL (1998) Portaria $n^{\circ}$ 527, de 31 de dezembro de 1997. Institui o Registro Nacional de Cultivares. Available at < https://www.jusbrasil. com.br/diarios/944335/pg-41-secao-1-diario-oficial-da-uniao-doude-07-01-1998>. Accessed on October 13, 2020.

BRASIL (2003) Lei $n^{\circ} 10.711$ de 5 de agosto de 2003. Dispõe sobre o sistema nacional de sementes e mudas e dá outras providências. Available at < http://www.planalto.gov.br/ccivil_03/leis/2003/ |10.711.htm>. Accessed on November 24, 2020.

Câmara CRS, Urrea CA and Schlegel V (2013) Pinto beans (Phaseolus vulgaris L.) as a functional food: Implications on human health. Agriculture 3: 90-111.
Carbonell SAM, Carvalho CRL and Pereira VR (2003) Qualidade tecnológica de grãos de genótipos de feijoeiro cultivados em diferentes ambientes. Bragantia 62: 369-379.

Carbonell SAM, Chiorato AF, Bezerra LMC, Gonçalves JGR, Silva DA, Esteves JAF, Benchimol-Reis LL, Carvalho CRL, Barros VLNP, Freitas RS, Ticelli $M$ and Gallo PB (2019) IAC 1850: High yielding carioca common bean cultivar. Crop Breeding and Applied Biotechnology 19: 378-381.

Carbonell SAM, Chiorato AF, Bolonhezi D, Barros VLNP, Borges WLB, Ticelli M, Gallo PB, Finoto EL and Santos NCB (2014) "IAC Milênio" - Common bean cultivar with high grain quality. Crop Breeding and Applied Biotechnology 14: 273-276.

Carbonell SAM, Chiorato AF, Carvalho CRL, Ramos Junior EU, Ito MA, Borges WLB, Ticelli M, Santos NCB and Gallo PB (2010) IAC Formoso: new carioca common bean cultivar. Crop Breeding and Applied Biotechnology 10: 374-376.

Carbonell SAM, Chiorato AF, Ito MF, Perina EF, Gonçalves JGR, Souza PS, Gallo PB, Ticelli M, Colombo CA and Azevedo Filho JA (2008) IACAlvorada and IAC-Diplomata: New common bean cultivars. Crop Breeding and Applied Biotechnology 8: 163-166.

Carbonell SAM, Guerreiro Filho O and Siqueira WJ (2012) Contributions of the Instituto Agronômico (IAC) for plant breeding. Crop Breeding and Applied Biotechnology 12: 15-24.

Chiorato AF, Carbonell SAM, Carvalho CRL, Barros VLNP, Borges WLB, Ticelli M, Gallo PB, Finoto EL and Santos NCB (2012) "IAC IMPERADOR": early maturity 'carioca' bean cultivar. Crop Breeding and Applied Biotechnology 12: 297-300.

Chiorato AF, Carbonell SAM, Gonçalves JGR, Silva DA, Benchimol-Reis LL, 
The research, development, and innovation trajectory of the IAC Common Bean Breeding Program

Carvalho CRL, Barros VLNP, Freitas RS, Ticelli M, Gallo PB and Santos NCB (2018a) IAC Sintonia: new carioca common bean cultivar. Crop Breeding and Applied Biotechnology 18: 338-342.

Chiorato AF, Carbonell SAM, Vencovsky R, Fonseca Júnior NS and Pinheiro JB (2010) Genetic gain in the breeding program of common beans at IAC from 1989 to 2007. Crop Breeding and Applied Biotechnology 10: $329-336$.

Chiorato AF, Reis LLB, Bezerra LMC and Carbonell SAM (2018b) Global vision on common bean breeding cultivars. In Campos-Vega R, Bassinello PZ, and Oomah BD (eds) Phaseolus vulgaris: Cultivars, production and uses. Nova Science Publishers, New York, p. 27-68.

Curran J (2012) The nutritional value and health benefits of pulses in relation to obesity, diabetes, heart disease and cancer. British Journal of Nutrition 108: 1-2.

Darmon N and Drewnowski A (2015) Contribution of food prices and diet cost to socioeconomic disparities in diet quality and health: a systematic review and analysis. Nutrition Reviews 73: 643-660.

Debouck D, Van Schoonhoven A and Voysest O (1991) Common beans: research for crop improvement. Systematics and morphology. Commonwealth Agricultural Bureaux International, Wallingford, p. 55-118.

Furlani AMC and Viégas GP (1993) O melhoramento de plantas no Instituto Agronômico. Instituto Agronômico, Campinas, 524p.

Gonçalves JGR, Andrade ER, Silva DA, Esteves JAF, Chiorato AF and Carbonell SAM (2019) Drought tolerance evaluated in common bean genotypes. Ciência e Agrotecnologia 43: 1-9.

Hartmann C and Siegrist M (2017) Consumer perception and behaviour regarding sustainable protein consumption: A systematic review. Trends in Food Science \& Technology 61: 11-25.
Hayat I, Ahmad A, Masud T, Ahmed A and Bashir S (2014) Nutritional and health perspectives of beans (Phaseolus vulgaris L.): An overview. Critical Reviews in Food Science and Nutrition 54: 580-592.

Maringoni AC, Ishiszuka MS, Silva AP, Soman JM, Moura MF, Santos RL, Silva João TAF, Chiorato AF, Carbonell SAM and Fonseca NS (2015) Reaction and colonization of common bean genotypes by Curtobacterium flaccumfaciens pv. flaccumfaciens. Crop Breeding and Applied Biotechnology 15: 87-93.

Messina V (2014) Nutritional and health benefits of dried beans: Discovery service for endeavour college of natural health library. The American Journal of Clinical Nutrition 100: 437.

Pompeu AS (1993) Feijão. In Furlani AMC and Viégas GP (eds) 0 melhoramento de plantas no Instituto Agronômico. Instituto Agronômico, Campinas, p. 111-155

Ramalho MAP, Dias LAS and Carvalho BL (2012) Contributions of plant breeding in Brazil: progress and perspectives. Crop Breeding and Applied Biotechnology 12: 111-120.

Ribeiro T, Azevedo CVG, Esteves JAF, Carbonell SAM, Ito MF and Chiorato AF (2017) Reaction of common bean lines to Xanthomonas axonopodis pv. phaseoli and Curtobacterium flaccumfaciens pv. flaccumfaciens. Crop Breeding and Applied Biotechnology 17: 40-46.

Santos FS, Aviani DM, Hidalgo JAF, Machado RZ and Araújo SP (2012) Evolution, importance and evaluation of cultivar protection in Brazil: the work of the SNPC. Crop Breeding and Applied Biotechnology 12: 99-110.

Spitti AMDS, Carbonell SAM, Dias CTS, Sabino LG, Carvalho CRL and Chiorato AF (2019) Carioca bean genotypes for tolerance to grain darkening by natural and accelerated methods. Ciência e Agrotecnologia 43: 1-10. 